\title{
Knowledge of Patients with Mechanical Valve Prostheses Concerning Chronic Oral Anticoagulant Therapy
}

\author{
Helena Teixeira Rocha ${ }^{1}$ \\ Eneida Rejane Rabelo² \\ Graziella Aliti3 \\ Emiliane Nogueira de Souza ${ }^{4}$
}

\begin{abstract}
Adherence to chronic Oral Anticoagulant Therapy (OAT) is directly related to patients' understanding of the therapy. This study verified the knowledge of patients with mechanical valve prostheses concerning OAT. This is a contemporary cross-sectional study, the sample is composed of patients with mechanical valve prostheses (MVP) in outpatient follow-up. A 10-question instrument was used; answers were 'know' (1 point), 'know partially' (half point), or 'do not know' (zero). Patients were grouped according to the result obtained: $\leq 4$ points was considered insufficient knowledge; $>4 \leq 8$ equated to moderate knowledge; and $>8$ was considered appropriate knowledge. Of the 110 patients, $61.8 \%$ presented moderate knowledge, $40.9 \%$ were not able to name at least one factor that may alter the INR (International Normalized Ratio) and $37.3 \%$ were not able to report their INR target range. The majority of patients presented moderate knowledge concerning the treatment. Strategies to improve knowledge on the topic should be implemented to minimize risks.
\end{abstract}

Descriptors: Anticoagulants; Nursing; Knowledge; Heart Valve Prosthesis.

\footnotetext{
${ }^{1}$ RN, Specialist in Cardiology Nursing, Hospital São Francisco, Complexo Hospitalar, Santa Casa de Misericórdia de Porto Alegre, RS, Brazil. E-mail: helena@mdsinfo.com.br.

${ }^{2}$ RN, Ph.D. in Biological Sciences, Adjunct Professor, Escola de Enfermagem, Universidade Federal do Rio Grande do Sul, RS, Brazil. Professor, Instituto de Cardiologia, Fundação Universitária de Cardiologia, RS, Brazil. E-mail: rabelo@portoweb.com.br.

${ }_{3}^{3}$ Professor, Instituto de Cardiologia, Fundação Universitária de Cardiologia, RS, Brazil. E-mail: grazialiti@gmail.com.

${ }^{4}$ RN, M.Sc. in Health Sciences, Assistant Professor, Universidade Federal de Ciências da Saúde de Porto Alegre. Professor, Instituto de Cardiologia, Fundação Universitária de Cardiologia, RS, Brazil. E-mail: enogsouza@hotmail.com.
}

Corresponding Author:

Emiliane Nogueira de Souza

Universidade Federal de Ciências da Saúde de Porto Alegre

Rua Sarmento Leite, 245/411

Centro

CEP: 90050-170 Porto Alegre, RS, Brasil

E-mail: enogsouza@hotmail.com 


\section{Conhecimento de pacientes portadores de prótese valvar mecânica sobre a terapia com anticoagulação oral crônica}

A adesão à terapia com anticoagulação oral crônica está diretamente relacionada ao entendimento dos pacientes sobre essa terapia. O objetivo deste estudo foi verificar o conhecimento dos pacientes, com prótese valvar mecânica, sobre terapia de anticoagulação oral. Como método, usou-se o estudo transversal contemporâneo. Incluem-se pacientes com prótese valvar mecânica (PVM) em acompanhamento ambulatorial. Aplicou-se instrumento com 10 questões. As respostas eram sabe (um ponto), sabe parcialmente (meio ponto), ou não sabe (zero). Os pacientes foram agrupados conforme a pontuação obtida. Considerou-se $\leq 4$ pontos conhecimento insuficiente, $>4 \leq 8$ conhecimento regular e $>8$ conhecimento adequado. Os resultados mostram que, dos 110 pacientes, $61,8 \%$ apresentaram conhecimento regular, 40,9\% não souberam citar ao menos um fator que alterasse a razão normatizada internacional (RNI) e 37,3\% não souberam informar o seu RNI alvo. Conclui-se que a maioria dos pacientes apresentou conhecimento regular sobre o tratamento. Estratégias devem ser implementadas para melhorar o conhecimento e, consequentemente, minimizar os riscos dessa terapêutica.

Descritores: Anticoagulantes; Enfermagem; Conhecimento; Próteses Valvulares Cardíacas.

\section{Conocimiento de los pacientes portadores de prótesis valvular mecánica sobre la terapia de anticoagulación oral crónica}

El objetivo de este estudio fue verificar el conocimiento de pacientes con prótesis valvular sobre la terapia de anticoagulación oral. La adhesión a la terapia de anticoagulación oral crónica está directamente relacionada al entendimiento del paciente sobre esta terapia. Se trata de un estudio transversal contemporáneo, en el cual se incluyeron pacientes de ambulatorio con prótesis valvular mecánica (PVM). Se aplicó un cuestionario con 10 preguntas; las respuestas fueron "sabe" (1 punto), "sabe parcialmente" (medio punto), "no sabe" (cero puntos). Los pacientes fueron agrupados según la puntuación obtenida: $\leq 4$ puntos, conocimiento insuficiente; $>4 \leq 8$ puntos, conocimiento regular; $>8$ puntos, conocimiento adecuado. De los 110 pacientes incluidos, el 61,8\% demostró conocimiento regular, 40,9\% no supieron citar un factor que altera el REI (razón estandarizada internacional) y $37,3 \%$ no supieron informar su REI objetivo. Se concluyó que la mayoría de los pacientes demostró conocimiento regular sobre el tratamiento. Se recomienda implantar estrategias para mejorar el conocimiento y minimizar los riesgos de la terapia.

Descriptores: Anticoagulantes; Enfermería; Conocimiento; Prótesis Valvulares Cardíacas.

\section{Introduction}

Patients with mechanical valve prostheses need to receive chronic therapy with oral anticoagulants in order to reduce the occurrence of thromboembolic events $^{(1)}$. Treatment with oral anticoagulants consists of maintaining the International Normalized Ratio (INR), which allows one to evaluate the plasma clotting time within the therapeutic range values.
The INR therapeutic values for aortic valve prosthesis are between 2.0 and 3.0 and between 2.5 and 3.5 for mitral valve replacement, according to the World Health Organization(2-4). Nevertheless, this therapy has limitations in clinical practice due to the difficulty for health professionals of keeping patients' INR values within therapeutic specifications. National and 
international data indicate that $40 \%$ to $50 \%$ of patients undergoing oral anticoagulant therapy do not meet the target values, which leads to an increased risk of bleeding or thrombotic events ${ }^{(5-6)}$.

The knowledge of patients concerning oral anticoagulant therapy is very diversified. The Early SelfControlled Anticoagulation Trial (ESCAT) verified that anticoagulant patients who used an electronic device to verify their INR at home had an improved survival rate of about 33\%, compared to a group of individuals who did not use such a device ${ }^{(7)}$. On the other hand, results of a similar study developed in São Paulo, Brazil did not present favorable results for the use of an electronic device $^{(5)}$. In another study involving knowledge of oral anticoagulants among different ethnic groups, only $9 \%$ of anticoagulant patients were able to name one or more of the adverse effects of anticoagulant medication(6).

A previous study indicates that knowledge concerning anticoagulants was associated with a reduced risk of bleeding ${ }^{(8)}$ and that written and verbal information helped to improve control of anticoagulant levels ${ }^{(9)}$.

Because there are few Brazilian studies addressing the issue and also considering that oral anticoagulation is directly related to the understanding of patients concerning their medication, its benefits and related adverse events, this study verified knowledge concerning the use of chronic anticoagulation treatment in patients with mechanical valve prostheses.

\section{Method}

A cross-sectional study was carried out between October 2007 and February 2008 in an outpatient clinic specializing in cardiology in two hospitals in Porto Alegre, RS, Brazil. Users of the Single Health System, 18 years old or older, with mechanical valve prostheses, taking oral anticoagulation medication and who attended consultations in the clinic were included in the study. All patients included in the study were accompanied in this clinic and underwent valve replacement in the same studied institutions. No patients were excluded from the study. Data collection was carried out through an instrument composed of 11 questions: the ten first questions addressed knowledge and the last one the level of patient satisfaction regarding information received concerning oral anticoagulation medication.

The instrument contained the following options of responses: 'know', 'know partially' or 'do not know'; a half point was awarded for 'know partially' and one point for 'know'. Thus, based on a study that evaluated anticoagulant patients with several indicators, we considered insufficient knowledge as up to four points (inclusive), moderate knowledge from four to eight points (inclusive), and appropriate knowledge above eight points $^{(10)}$. The data collection instrument was adapted from a British study carried out by Sunil Nadar and colleagues $^{(11)}$, whose use was authorized by the group's coordinator Gregory Y. H. Lip. The English version was initially translated to Portuguese and then submitted to face validation ${ }^{(12)}$. This stage involved a multidisciplinary team and researchers in the field; idiomatic, semantic, cultural and conceptual equivalences were performed in order to improve the consensus concerning the instrument. Hence, the instrument was evaluated by six judges who were health professionals directly or indirectly involved with anticoagulant patients (two physicians, two nurses and two nutritionists). All suggestions were considered, including the exclusion of a dubious question that was also different form the other constructs.

The instrument that verifies the knowledge of patients regarding oral anticoagulant therapy was directly applied to the patients by the study's researcher, after securing their agreement, in the outpatient clinic itself on the days the patients' OATs were scheduled. A pilot test was carried out before data collection with ten patients to refine the instrument. There were not $100 \%$ of answers 'know partially' or 'do not know' for any questions and no patients answered 'know partially' or 'do not know' to all questions. Therefore, all questions were maintained.

The sample was computed in such a way the instrument was applied to ten patients per question, which is recommended to evaluate internal reliability through Cronbach's alpha(13).

This study was approved by the Ethics Research Committee of both institutions (N. 4029/07) and all patients were included after reading and signing free and informed consent forms.

\section{Statistical Analysis}

Data were analyzed through the Statistical Package for Social Sciences, version 12.0. All categorical variables were expressed in absolute numbers and their percentages; continuous variables were described with average \pm standard deviation or median and percentiles 25 and 75, as they fit normal distribution or not. Person's correlation was used to evaluate the correlation between the obtained score and the studied variables such as 'time of surgery' and 'schooling'. To compare the score average in relation to the variables 'gender' and 'professional status', the $t$ test was used. 
In relation to the comparison between the score and the position of the valve prosthesis, variance analysis was used. Cronbach's reliability test was used to evaluate and measure the internal consistency of the applied questionnaire while the values $>0.7$ were considered ideal to evaluate consistency of the same construct(13).

\section{Results}

A total of 110 patients were evaluated. The internal consistency, evaluated through Cronbach's alpha, was 0.627 . Average age was $50.3 \pm 10.7$ years old and $58.2 \%$ were female; average of years of schooling was $6.07 \pm 2.98$ years and $44.5 \%$ of the patients were retired. Mitral valve replacement (62.7\%) and the use of warfarin as anticoagulant (64.5\%) predominated. Data are shown in Table 1.

Table 1 - Characteristics of a sample of anticoagulant patients in a specialized outpatient clinic $(n=110)$. Porto Alegre, RS, Brazil 2009

\begin{tabular}{lcc}
\multicolumn{1}{c}{ Characteristics } & n & (\%) \\
\hline Age $^{*}$ & \multicolumn{3}{c}{$50.3 \pm 10.7$} \\
Gender (male) & 46 & \multicolumn{2}{c}{$(41.8)$} \\
Years of Schooling * & \multicolumn{3}{c}{$6.07 \pm 2.98$} \\
Surgery Data & \multicolumn{3}{|c}{} \\
from 1980 to 1997 & 19 & $(17.1)$ \\
from 1998 to 2002 & 47 & $(42.7)$ \\
from 2003 to 2007 & 44 & $(40)$ \\
Race (Caucasian) & 97 & $(88.2)$
\end{tabular}

Continue...
Table 1 - Continuation

\begin{tabular}{lll}
\hline \multicolumn{1}{c}{ Characteristics } & $\mathbf{n}$ & $(\%)$ \\
\hline Professional status & 18 & $(16.4)$ \\
$\quad$ Working & 49 & $(44.5)$ \\
Retired & 27 & $(24.5)$ \\
Unemployed & 16 & $(14.5)$ \\
$\quad$ Sick leave & & \\
Position of prosthesis & 69 & $(62.7)$ \\
$\quad$ Mitral & 31 & $(28.2)$ \\
$\quad$ Aortic & 10 & $(9.1)$ \\
$\quad$ Mitral and aortic & 71 & $(64.5)$ \\
Anticoagulant (warfarin) &
\end{tabular}

Categorical data are presented with $\mathrm{n}(\%) ;$ *Variable expressed with average \pm standard deviation

Most of the patients were able to report the name of the oral anticoagulant they were using, the medication's function, why they were using it, and the dose they were currently using. We highlight that $36 \%$ of the patients were not able to name at least one side effect of the oral anticoagulant. Of the interviewed patients, $10.9 \%$ were not able to tell what could happen if they did not take the anticoagulant and $37.3 \%$ did not know what the their ideal INR value was. When asked about factors that could interfere in their INR, 40.9\% answered 'do not know' and nor were they able to name at least one factor that could interfere in it. Also, $21.8 \%$ of the sample was not able to list the precautions they should take given the use of the therapy (Table 2).

Table 2 - Knowledge of patients concerning chronic anticoagulant therapy. Porto Alegre, RS, Brazil 2009

\begin{tabular}{|c|c|c|c|}
\hline Questions & know & Know partially & Do not know \\
\hline 1. What is the name of the anticoagulant you are taking? & $109(99.1)$ & - & $1(0.9)$ \\
\hline 2. Do you know the function of this medication? & $103(93.6)$ & $5(4.5)$ & $2(1.8)$ \\
\hline 3. Do you know why you are taking this medication? & $76(69.1)$ & $16(15.5)$ & $18(16.4)$ \\
\hline 4. Can you tell what the OAT side effects are? (At least 1 ). & $46(41.8)$ & $28(25.5)$ & $36(32.7)$ \\
\hline 5. What is the dose of OAT you are currently taking? & $107(97.3)$ & $3(2.7)$ & - \\
\hline 6. How long have you been taking OAT? & $110(100)$ & - & - \\
\hline 7. What can happen if you do not take OAT? & $72(65.5)$ & $26(23.6)$ & $12(10.9)$ \\
\hline 8. What is your target INR? & $55(50)$ & $14(12.7)$ & $41(37.3)$ \\
\hline 9. Do you know what factors can interfere with your INR levels? (At least 1). & $43(39.1)$ & $22(20)$ & $45(40.9)$ \\
\hline $\begin{array}{l}\text { 10. Do you know what precautions you have to take due to the use of OAT? (At least 2: physical } \\
\text { exercise, identification card, diet, activities before procedures, INR periodical control). }\end{array}$ & $44(40)$ & $42(38.2)$ & $24(21.8)$ \\
\hline
\end{tabular}

INR: International Normalized Ratio; OAT: Oral Anticoagulation Therapy. Categorical Data are presented with $\mathrm{n}(\%)$.

In relation to the score obtained in the instrument, the majority $(68 ; 61.8 \%)$ presented regular knowledge, followed by $40(36.4 \%)$ patients who had good knowledge and two $(1.8 \%)$ who had poor knowledge.
Correlation between anticoagulation time and the instrument score was evaluated and was not significant $(r=0.183 ; P=0.056)$. Evaluating the age of the interviewees and score obtained revealed a 
significant inverse correlation $(r=-0.248 ; P=0.009)$. In the items 'schooling' and 'correct answers', a positive and significant, though weak correlation, was found $(r=0.276 ; P=0.03)$.

There were no differences between gender and score obtained in the questionnaire and professional status. We note that patients with mitral and aortic valve prostheses (9.1\%) obtained better average, 8.45 \pm 0.95 , though not statistically significant.

\section{Discussion}

This study aimed to verify knowledge of the use of chronic oral anticoagulation in patients with mechanical valve prostheses. It showed that patients presented regular knowledge about oral anticoagulant therapy and there was no relation between gender and professional status with knowledge score. The results of another study conducted in the nursing field in which $64 \%$ of patients answered correctly almost the entire questionnaire addressing oral anticoagulation knowledge with the exception of one question addressing the influence of diet, were similar(10). However, the results of this study differ from those found by other researchers who evaluated patients with mechanical valve prostheses and evidenced poor knowledge regarding warfarin therapy. This same study evidenced that the predictors of a better understanding of treatment were knowing the meaning of INR, being young and obtaining information concerning anticoagulation upon hospital discharge ${ }^{(14)}$.

The scenarios of clinical practice in which patients control the levels of anticoagulation are diversified, especially in relation to professionals in the health field and the way information is transmitted to patients. In mid 1950s, scientific thinking concerning the success of anticoagulation therapy was composed of four main variables: medical surveillance, reliable laboratory work, easily available exams and collaboration of patients with the treatment ${ }^{(15)}$. Over the years, one of the variables experienced an important and necessary development. Due to the increasing number of anticoagulant patients, medical surveillance now includes outpatient follow-up performed by other health professionals, among whom nurses are included. In this context, anticoagulation outpatient clinics, especially those directed to the monitoring of therapeutic practices associated with patients' education, emerged(16).

The most important factor in treatment success is periodical and careful follow-up of INR levels and assurance that patients will adhere to the treatment, which is a difficult task for clinical practice ${ }^{(17-19)}$. Despite the practical relevance of teaching patients regarding their therapy, a best strategy to educate patients about anticoagulation has yet to be determined(20).

RecentEuropeanstudiesindicatethatanticoagulation self-regulation that the patient controls when $s /$ he is taught is a successful strategy. Self-control is realized through a rapid test device, in which the patient adjusts the dose of his/her medication. Studies conducted from this perspective have shown that patients are able to keep their INR within therapeutic range longer and also show improved survival and diminished adverse effects $^{(1,3,21)}$.

Studies involving other approaches for anticoagulation control such as telephone contact, also present positive results, both for patients and the team monitoring them(22).

About half of this study's sample knew their target INR values and this information agrees with that found by a British study, in which more than half of patients knew the interval of their therapeutic INR. This British study carried out an educational program with intervention, which improved the knowledge of patients about the factors that might interfere with anticoagulation levels ${ }^{(23)}$. A significant share of the sample of the present study did not know what these factors are. In relation to the risks of treatment and its side effects, American researchers presented as an alternative the use and supply of a visual scale the illustrations of which are meant to demonstrate what might happen if the levels of anticoagulation are off the target values. The benefit of using this visual scale was significant to patients who had difficulty understanding the scheme of dosages that resulted in poor control of their anticoagulation levels ${ }^{(24)}$.

An expressive number of patients who were not able to mention at least one side effect was found in the present study; they were unaware there was a possibility of bleeding. The number of patients in this sample who were not able to list care related to the therapy is also noteworthy, such as medication interaction, the influence of a diet rich in vitamin $\mathrm{K}$, and necessary care before invasive procedures (extractions for example). They only mention monthly laboratorial control as the main necessary care. It is known that a successful therapy requires the adherence of patients, which enables maximum knowledge concerning anticoagulant therapy to be transmitted. Nurses and other professionals are expanding the boundaries of their practice in anticoagulation outpatient clinics to improve the stability of patients' INR. 
The patients' return visits to the anticoagulation outpatient clinic should be an opportunity to investigate difficulties they face, especially among those who are not able to keep anticoagulation within appropriate levels. The patients' educational process has began a new era in which educational results should take into account the level of patients' literacy, barriers to learning and cost-effectiveness relationships, giving priority to educational content and using validated instruments to measure the results of instruction provided ${ }^{(25)}$. It is necessary to recognize that the assisted individuals develop, due to their experiences, a certain understanding of procedures and recommendations defended by the health services and, consequently, certain attitudes in relation to them. Thus, scientific knowledge needs to be contextualized, confronted and approximated to other types of knowledge, especially folk knowledge so it becomes useful knowledge(26). Additionally, it is necessary that health professionals welcome and establish bonds with the individuals they are assisting, respecting their autonomy in relation to their way of life ${ }^{(26)}$. These competencies include listening to patients acknowledge their health needs, establishing close and candid relationships, and relating and integrating with the assisted individuals.

\section{Final Considerations}

The majority of patients included in this study presented regular knowledge concerning their anticoagulant therapeutic, especially in relation to side effects, factors that interfere in their INR levels and care required by oral anticoagulant therapy. Given these findings, we suggest patients with mechanical valve prostheses have a multidisciplinary approach initiated during hospitalization, reinforced at the point of discharge and to last at least six to twelve months or until the patient is stable and familiarized with the therapy and his/her INR level.

\section{References}

1. Koertke H, Zittermann A, Wagner O, Koerfer R. Selfmanagement of oral anticoagulation therapy improves long-term survival in patients with mechanical heart valve replacement. Ann Thorac Surg. 2007;83(1):24-9.

2. Kulik A, Bédard P, B-Khanh L, Rubens FD, Hendry PJ, Masters RG, et al. Mechanical versus bioprosthetic valve replacement in middle aged patients. Eur J Cardiothorac Surg. 2006;30(3):485-91.

3. Christensen TD, Andersen NT, Attermann J, Hjortdal VE, Maegaard M, Hasenkam M. Mechanical heart valve patients can manage oral anticoagulation therapy themselves. Eur J Cardiothorac Surg. 2003;23(3):292-8.

4. Katz B, Marques MB. Point-of-care testing in oral anticoagulation: what is the point? MLO Med Lab Obs. 2004;36(3):30-5.

5. De Piano LPA, Strunz CMC, Mansur AP, Rached RA. Comparação entre os resultados do índice de normalização internacional medidos em dispositivo portátil (Hemochron Jr.) e por metodologia convencional. Arq Bras Cardiol. 2007;88(1):31-4.

6. Ansell J, Hirsh J, Dalen J, Bussey H, Anderson D, Poller $\mathrm{L}$, et al. Managing oral anticoagulant therapy. Chest. 2001;119Suppl:22S-38S.

7. Koertke H, Breymann Th, Minami K, Seifert D, Arusoglu L, Koerfer R. Early start of INR self-management (INR-S) after mechanical valve replacement. Eur Heart J. 2000;21 Suppl:266.

8. Kagansky N, Knobler H, Rimon E, Ozer Z, Levy S. Safety of anticoagulation therapy in well-informed older patients. Arch Intern Med. 2004;164(18):2044-50.

9. Tang EO, Lai CS, Lee KK, Wong RS, Cheng G, Chan TY. Relationship between patients' warfarin knowledge and anticoagulation control. Ann Pharmacother. 2003;37(1):34-9.
10. Henn CB, Rabelo ER, Boaz M, Souza EN. Conhecimento dos pacientes sobre anticoagulação oral crônica acompanhados em ambulatório especializado. Rev Gaúch Enferm. 2008;29(2):207-13.

11. Nadar S, Begum N, Kaur B, Sandhu S, Lip GYH. Patients' understanding of anticoagulant therapy in a multiethnic population. J R Soc Méd. 2003;96(4):175-9.

12. Góes PSA, Fernandes LMA, Lucena LBS. Validação de instrumentos de coleta de dados. In: Nunes JLF, Peres MA, editors. Epidemiologia da saúde bucal. Rio de Janeiro: Guanabara Koogan; 2006.

13. Gliem JA, Gliem RR. Calculating, interpreting and reporting Cronbach's alpha reliability coefficient for likert-types scales. In: Midwest Research to Pratice conference in Adult, Continuing and community Education, October 8-10. Columbus; 2003.

14. Hu A, Chow CM, Dao D, Errett L, Keith M. Factors influencing patient knowledge of warfain therapy after mechanical heart valve replacement. J Cardiovasc Nurs. 2006; 21(3):169-75.

15. Askey JM, Cherry CB. Thromboembolism associated with auricular fibrillation: continuous anticoagulant therapy. JAMA. 1950;144(2):97-100.

16. Ruibarreira JR, Farinha M, Martins R, Rodrigues I, Mendes Z, Crespo F. Monitorização da terapêutica com anticoagulantes orais: consulta de anticoagulação vs médico assistente. Acta Med Port. 2004;17(6):413-6.

17. Lourenço DM, Lopes LHC, Vignal CV, Morelli VM. Avaliação clínica e laboratorial de pacientes em uso de anticoagulantes orais. Arq Bras Cardiol. 1997;68(5):353-6.

18. Newall F, Monagle $P$, Johnston L. Patient understanding of warfarin therapy: a review of education strategies. Hematology. $2005 ; 10(6): 437-42$. 
19. Rodrigues FFL, Zanetti ML, Santos MA, Martins TA, Sousa VD, Teixeira CRS. Knowledge and attitude: important components in diabetes education. Rev. Latino-Am. Enfermagem. 2009; 17(4):468-73.

20.Cromheecke ME, Levi M, Colly LP, Mol JMB, Prins MH, Hutten $B A$, et al. Oral anticoagulation self-management and management by a specialist anticoagulation clinic: a randomised cross-over comparison. Lancet. 2000;356(9224):97-102.

21. Waterman $A D$, Banet $G$, Milligan PE, Frazier $A$, Verzino $E$, Walton $B$, et al. Patient and physician satisfaction with a telephone-based anticoagulation service. J Gen Intern Med. 2001;16(7):460-3.

22. Lane DA, Ponsford J, Shelley A, Sirpal A, Gregory YH Lip. Patient Knowledge and perceptions of atrial fibrillation and anticoagulant therapy: Effects of an educational intervention programme. The West Birmingham Atrial Fibrillation Project. Int J Cardiol. 2006;110(3):354-8.
23. Matchtinger $E L$, Frances $W$, Chen $L L$, Rodriguez $M, W u S$, Schillinger D. A visual schedule to improve anticoagulation control: a randomized, controlled trial. Jt Comm J Qual Patient Saf. 2007;33(10):625-35.

24. Wofford JL, Wells MD, Singh S. Best strategies for patient education about anticoagulation with warfarin: a systematic review. BMC Health Serv Res. 2008;8:40.

25. Crowther MA, Ageno W, Garcia D, Wang L, Witt DM, Clark $N P$, et al. Oral Vitamin $K$ Versus Placebo to Correct Excessive Anticoagulation in Patients Receiving Warfarin. Ann Intern Med. 2009;150(5):293-300.

26. Leonello VM, Oliveira MAC. Competências para ação educativa da enfermeira. Rev. Latino-Am. Enfermagem. 2008;16(2):177-83. 